\title{
Occurrence of virulence-related sequences and phylogenetic analysis of commensal and pathogenic avian Escherichia coli strains (APEC) ${ }^{1}$
}

\author{
Tatiana Amabile de Campos², Juliana Carvalhães Lago², Gerson Nakazato², \\ Eliana Guedes Stehling ${ }^{2}$, Marcelo Brocchi², Antônio Fernando Pestana de \\ Castro $^{3}$ e Wanderley Dias da Silveira ${ }^{2 *}$
}

\begin{abstract}
Campos T.A., Lago J.C., Nakazato G., Stehling E.G., Brocchi M., Castro A.F.P. \& Silveira W.D. 2008. Occurrence of virulence-related sequences and phylogenetic analysis of commensal and pathogenic avian Escherichia colistrains (APEC). Pesquisa Veterinária Brasileira 28(10):533-540. Departamento de Microbiologia e Immunologia, Instituto de Biologia, Unicamp, Cidade Universitrária Zeferino Vaz $\mathrm{s} / \mathrm{n}$, Campinas, SP 13081-862, Brazil. E-mail: wds@unicamp.br

The presence of iron uptake (irp-2, fyuA, sitA, fepC, iucA), adhesion (iha, IpfA ${ }_{0157 / 0141}$, IpfA $\mathrm{A}_{\mathrm{157/0154}}$, efa, toxB) and invasion (inv, ial-related DNA sequences and assignment to the four main Escherichia coli phylogenetic groups (A, B1, B2 e D) were determined in 30 commensal $E$. coli strains isolated from healthy chickens and in 49 APEC strains isolated from chickens presenting clinical signs of septicemia $(n=24)$ swollen head syndrome $(n=14)$ and omphalitis $(n=11)$ by PCR. None of the strains presented DNA sequences related to the inv, ial, efa, and toxB genes. DNA sequences related to $I p f A_{0157 / 0154}$, iucA, $f e p C$, and irp-2 genes were significantly found among pathogenic strains, where iucA gene was associated with septicemia and swollen head syndrome and fepC and irp-2 genes were associated with swollen head syndrome strains. Phylogenetic typing showed that commensal and omphalitis strains belonged mainly to phylogenetic Group A and swollen head syndrome to phylogenetic Group D. Septicemic strains were assigned in phylogenetic Groups A and D. These data could suggest that clonal lineage of septicemic APEC strains have a multiple ancestor origin; one from a pathogenic bacteria ancestor and other from a non-pathogenic ancestor that evolved by the acquisition of virulence related sequences through horizontal gene transfer. Swollen head syndrome may constitute a pathogenic clonal group. By the other side, omphalitis strains probably constitute a non-pathogenic clonal group, and could cause omphalitis as an opportunistic infection. The sharing of virulence related sequences by human pathogenic $E$. coli and APEC strains could indicate that APEC strains could be a source of virulence genes to human strains and could represent a zoonotic risk.
\end{abstract}

INDEX TERMS: Avian colibacillosis, Escherichia coli, APEC, virulence related-genes, pathogenic clones.

\footnotetext{
${ }^{1}$ Received on September 18, 2007.

Accepted for publication on June 18, 2008.

2 Depto Microbiologia e Imunologia, Instituto de Biologia, Cx. Postal 6109, Universidade Estadual de Campinas (Unicamp), Cidade Universitária Zeferino Vaz s/n, Barão Geraldo, Campinas, SP 13081-862, Brazil. *Corresponding author: wds@unicamp.br

${ }^{3}$ Depto Microbiologia, Instituto de Ciências Biomédicas II, Av. Prof. Lineu Prestes $1374,2^{\circ}$ andar, Universidade de São Paulo (USP), São Paulo, SP 05505-900, Brazil.
}

RESUMO.- [Ocorrência de seqüências relacionadas com a virulência e análise filogenética de estirpes comensais e patogênicas de Escherichia coli aviário (APEC).] A presença de seqüências de DNA associadas à capacidade de captação de ferro (irp-2, fyuA, sitA, fepC, iucA), adesão (iha, IpfA $\mathrm{O} 157 / 0141_{1}$, IpfA ${ }_{\mathrm{O} 157 / 0154}$, efa, toxB) e de invasão (inv, ial) e a classificação dentro dos quatro grupos filogenéticos principais de Escherichia coli (Grupos A, B1, B2 e D) foram determinadas, através de PCR, em 
30 amostras comensais de $E$. coli isoladas de frangos e de 49 linhagens APEC (24 isoladas de frangos com septicemia, 14 isoladas de frangos com síndrome da cabeça inchada e 11 isoladas de embriões de galinhas com onfalite). Nenhuma das linhagens apresentou os genes inv, ial, efa, e toxB. Os genes $/ p f A_{\mathrm{O} 157 / 0154}$, iucA, fepC e irp-2 foram encontrados em freqüências significativas entre as amostras patogênicas. O gene iucA foi associado com amostras causadoras de septicemia e de síndrome da cabeça inchada. Os genes fepC e irp-2 foram associados a amostras causadoras de síndrome da cabeça inchada. A análise filogenética demonstrou que linhagens comensais e causadoras de onfalite pertenceram principalmente ao Grupo filogenético $A$, não patogênico. Amostras causadoras de síndrome da cabeça inchada pertenceram, em sua maioria, ao Grupo patogênico D. Linhagens causadoras de septicemia pertenceram aos Grupos A e D. Estes dados sugerem que linhagens APEC causadoras de septicemia provavelmente têm uma origem ancestral múltipla: uma derivada de uma linhagem patogênica e outra de uma linhagem não patogênica que possivelmente evoluiu através da aquisição horizontal de genes de virulência. Amostras causadoras de síndrome da cabeça inchada possivelmente constituem um grupo clonal patogênico. Por outro lado, amostras causadoras de onfalite possivelmente constituem um grupo clonal não patogênico, que, possivelmente causam onfalite devido a uma infecção oportunista. A presença de genes de virulência também encontrados em $E$. coli de origem humana pode indicar a possível ocorrência de zoonoses causadas por APEC.

TERMOS DE INDEXAÇÃO: Colibacilose aviária, Escherichia coli, genes relacionados com a virulência, clones patogênicos.

\section{INTRODUCTION}

Avian pathogenic Escherichia coli (APEC) strains cause a variety of diseases in poultry, including respiratory tract infection, septicemia, omphalitis, swollen-head syndrome and enteritis, being responsible for significant economic losses in the chicken industry (Gross 1994). Although considerable efforts have been made in recent years to establish the pathogenic mechanisms of APEC strains, the pathogenic process and the role of the different virulence factors were not fully elucidated yet. Adherence and invasion to epithelial cells, flagella, toxins, colicin and cytotoxins production, serum resistance, outer membrane proteins expression, iron sequestering systems and temperature-sensitive hemagglutinin comprise virulence factors described for APEC strains and reviewed by DhoMoulin \& Fairbrother (1999) and La Ragione \& Woodward (2002). These virulence determinants can be mediated by the expression of chromosome or plasmids-located genes (Dozois et al. 2000, Parreira \& Gyles 2003, Stehling et al. 2003a,b, Tinvedale et al. 2004, Johnson et al. 2005, 2006, Kariyawasam et al. 2006).

APEC is a general term commonly used for $E$. coli isolated from avian colibacilosis, but a clear definition of pathotypes possibly associated with specific virulence genes or specific virulence assays is still missing (DhoMoulin \& Fairbrother 1999, Ngeleka et al. 2002, Ewers et al. 2004). Several studies trying to associate APEC virulence-related genes and pathogenic groups have been published. In this way, Type 1, P and curli adhesin genes (fim, pap, and csg clusters), thermo-sensible hemaglutinin (tsh), aerobactin genes (iuc, irp-2, fyuA), colicin (cva) and increased serum survival gene (iss) are frequently found among pathogenic strains (Maurer et al. 1998, JanBen et al. 2001, Knöbl et al. 2001, Ngeleka et al. 2002, Brito et al. 2003, Skyberg et al. 2003, Amabile de Campos et al. 2005, McPeake et al. 2005).

Some studies have demonstrated that APEC strains share virulence sequences with ExPEC (extra-intestinal pathogenic $E$. colli) isolated from humans. Rodriguez-Siek et al. (2005) showed that E. coli strains isolates obtained from human urinary tract infections (UTI) and avian colibacilosis could have substantial overlap in terms of serogroups, phylogenetic groups and virulence genotypes, including plasmid-DNA-related sequences, adhesion, iron uptake, protectins and toxins-related sequences. A previous subtractive hybridization analysis with two APEC strains and one E. coliK12 strain (Stocki et al. 2002) detected APEC specific DNA fragments presenting high homology with DNA sequences of E. coli O157: $\mathrm{H} 7$ and human ExPEC strains. JanBen et al. (2001) using PCR to detect virulence-related genes demonstrated that Yersinia spp genes necessary to iron uptake (fyuA and irp-2), pyelonephritis-associated pili $(p a p C)$ and enteroaggregative heat stable toxin gene (astA) of $E$. coligenes were frequently found among APEC isolated from internal organs of poultry died from colibacillosis. Johnson et al. (2003) recovered strains from chicken retails products that presented virulence profiles, phylogenetic group background, and $\mathrm{O}$ antigens resembling those of humans EXPEC isolates. Recently, a subtractive hybridization study performed with a human UTI E. coliand an avian colisepticemia strain demonstrated that both group of strains have common virulence determinants such as the TTSS (Type Three Secretion System) and iron uptake systems but they shared few virulence related sequences (Mokady et al. 2005). In this study it was observed that noncommon virulence-related DNA sequences found in ExPEC and APEC strains were phenotypically associated with the same pathogenic process. The authors suggested that both groups of strains were using different factors with similar roles in the various stages of the infection process: adhesion mediated by pilus, internalization by curli fibers, invasion, and persistence in the host by the iron uptake systems and by the evasion from the host immune system. Altogether, these studies suggest that since APEC and human ExPEC and diarrhegenic $E$. coli may encounter similar challenges when establishing infection, they could share similar virulence genes and capacities to cause disease, indicating that APEC could serve as a reservoir and source of virulence genes for human pathogenic E. coli such as ExPEC and Diarrheagenic E. coli. 
The aim of this work was to search for virulence-related genes described in human E. coli and other Enterobacteriaceae among APEC strains isolated in Brazil. For this purpose, we performed PCR detection of genes associated with adhesion, invasion and iron-uptake systems originally described in Yersinia (irp-2 and fyuA iron uptake related genes), Salmonella enterica Typhimurium (sitA siderophore gene), Enteroinvasive E. coli (EIEC, ial invasion gene), Enterohaemorrhagic E. coli (EHEC, fepC enterobactin gene and efa adhesion related sequence), and Shiga-toxin E. coli (STEC, Ipf, iha, toxB adhesins genes) among APEC strains isolated from chickens with septicemia, swollen head syndrome and omphalitis and strains isolated from healthy chickens (commensal strains). At the same time, all strains were classified into the main $E$. coli phylogenetic groups (A, $\mathrm{B} 1, \mathrm{~B} 2$ and $\mathrm{D}$ ) according to the methodology described by Clermont et al. (2000). These results were correlated with the presence of the genes above mentioned.

\section{MATERIALS AND METHODS}

\section{Bacterial strains}

Twenty four septicemia (S), 14 swollen head syndrome $(H)$, and 11 omphalitis $(\mathrm{O})$ Escherichia coli strains isolated from different outbreaks, and 30 commensal strains (C) isolated from chickens showing no signs of any of the above mentioned diseases and belonging to the Laboratory of Microbial Molecular Biology, Department of Microbiology and Immunology, Campinas State University (Unicamp), were studied. With the exception of commensal strains that were isolated from two different ranches located $50 \mathrm{~km}$ apart, all other strains were obtained from different outbreaks that had occurred in different regions of Brazil. Three colonies were isolated in each case and only one strain among those having the same plasmid and antimicrobial drug resistance profile was used to prepare a frozen stock. Strains were identified as $E$. coli by biochemical tests. Strains from septicemic cases were isolated from liver, air sacs and lung; swollen head syndrome strains were isolated from infraorbital sinuses and omphalitis strains were isolated from the yolk sacs of one-dayold chicks; commensal strains were collected from the cloacal region of healthy chickens. Bacterial strains used as positive control for PCR assays were listed at Table 1. HB101 K12 E. coli was used as negative control. All strains were kept at $-70^{\circ} \mathrm{C}$ in LB medium containing $15 \%$ glycerol final concentration.

Detection of virulence genes (yuA, irp-2, iucA, fepC, sitA, inv, toxB, iha , ial, efa, IpfA ${ }_{0157 / 01141}$, IpfA $\left._{\text {O157/01154 }}\right)$ and assignment to phylogenetic groups (chuA, yja and TspE4.C2) by PCR

Avian E. coli strains were analyzed by polymerase chain reaction (PCR) for the presence of the following iron acquisition related genes: ferric yersiniabactin (fyuA), iron repressible protein (irp-2), aerobactin synthetase (iucA), a protein component from ferric enterobactin transport $(f e p C)$ and the protein involved in the iron transport (sitA). The presence of invasion related genes

Table 1. Genes searched by PCR and primers sequences ${ }^{a}$

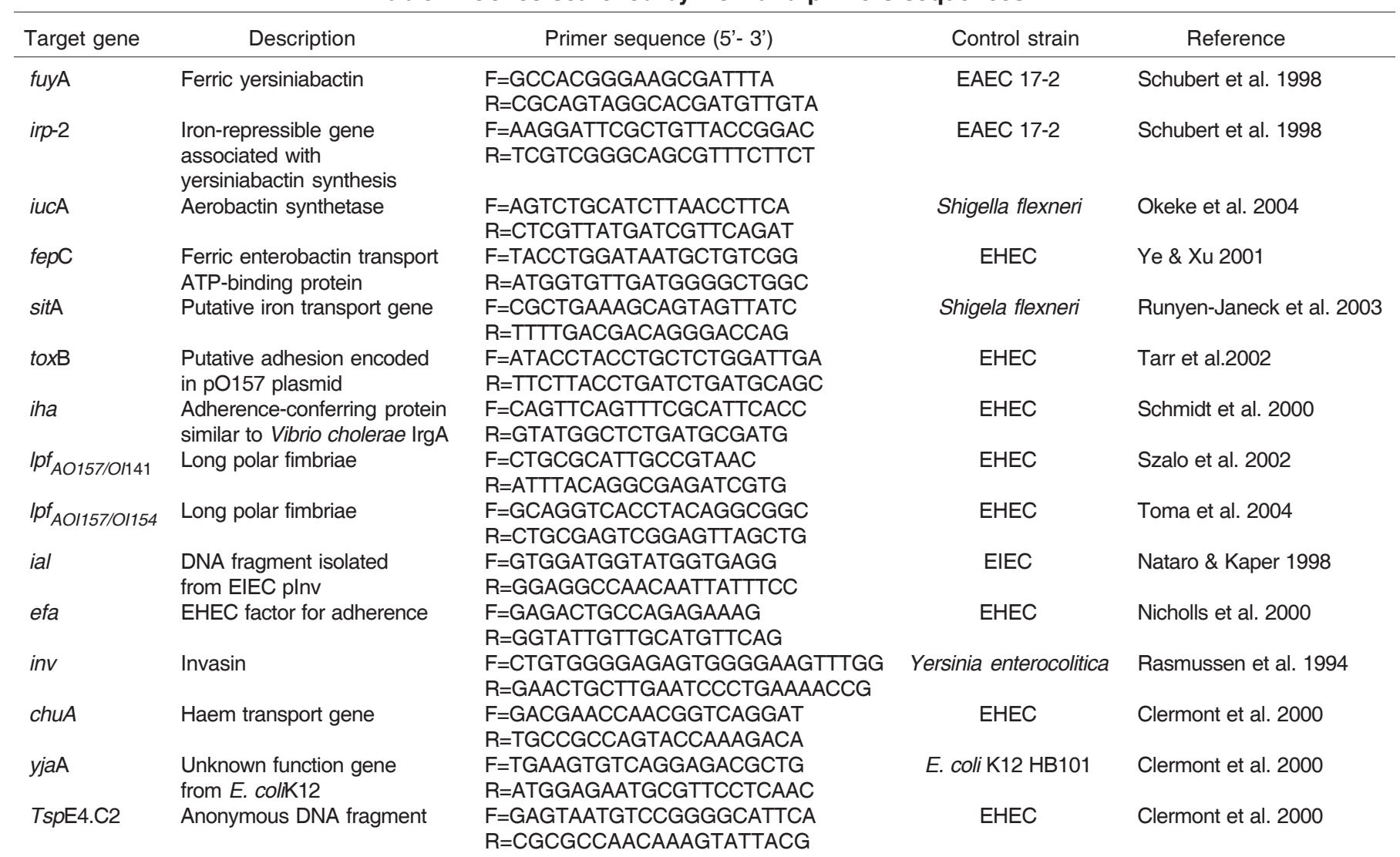

$\overline{\mathrm{a} F}=$ Forward, $\mathrm{R}=$ reverse. 
described for E. coli and Yersinia enterocolitica (ial and inv, respectively) and adhesion related genes described for STEC and EHEC (iha, toxB, IpfA ${ }_{0157 / 01141}$, IpfA $\mathrm{O} 157 / 01154_{1}$, efa) were also determined. PCR detection for chuA, yja and TspE4.C2 genes was used to determine the $E$. coli phylogenetic groups (A, B1, B2 and D) as described by Clermont et al. (2000). All the searched genes, specific primers, expected amplified DNA fragments and references are described in Table 1.

Genomic DNA was extracted and purified as described previously (Ausubel et al., 1988). The PCR reactions were prepared to contain 20ng of DNA, 10 pmol of each primer, $10 \mathrm{mM}$ of the four deoxynucleoside triphosphates (Invitrogen), PCR buffer (Invitrogen), and $1 \mathrm{U}$ of Taq polymerase (Invitrogen). All amplification reactions were performed at a "Mastercyle" thermocycle (Ependorff). PCR products were analyzed by gel electrophoresis in a $1.5 \%$ submersed agarose gel stained with ethidium bromide and visualized under UV light as described by Amabile de Campos et al. (2005).

\section{Statistical methods}

The $c^{2}$-test with Yates correction was used to determine the differences between strains isolated from healthy chickens (commensal strains) and those isolated from sick chickens (presenting clinical signs of septicemia, swollen head syndrome or omphalitis). Values of Pd"0.05 were considered to be significant.

\section{RESULTS}

We investigated 79 avian Escherichia coli strains (49 pathogenic and 30 commensal) for the presence of 12 virulence-related genes. None of the strains harbored inv, toxB, ial, and efa DNA related sequences. Sixteen strains (13 commensal and 3 septicemic) were negative to all sequences studied. The IpfA $\mathrm{O} 157 / \mathrm{Ol141}$ and iha genes were found in lower frequencies (detected in only 8 and 10 strains, respectively) and IpfA $\mathrm{O} 157 / 0 / 154_{\text {gene was the most }}$ frequent (Table 2). The following genes were identified with approximately equal frequencies among the strains: irp-2 (29\%), fyuA (26.5\%), fepC (25.3\%), sitA (25.3\%), and iucA $(37 \%)$. The virulence genes assayed were more frequently detected between the pathogenic strains than among the commensal ones (Table 2). Among commensal strains, sitA was the most frequent (27\%) virulence gene, followed by IpfA $\mathrm{O}_{\mathrm{O} 157 / 0154}(20 \%)$, irp-2 (13\%), fyuA (13\%), iucA (13\%), iha (6\%), fepC (3\%) and IpfA $\mathrm{O}_{157 / 01141}(3 \%)$ (Table 2). Among pathogenic strains, only septicemic strains presented all genes studied in this work. The iha gene was not detected among swollen head syndrome strains and the IpfA $\mathrm{O} 157 / 01141_{\text {sequence was not detected }}$ among swollen head syndrome and omphalitis strains (Table 2). Genes IpfA ${ }_{0157 / 01154}$, fepC, irp-2, iucA, and fyuA were found in higher frequencies in swollen head syndrome strains (100\%, 79\%, 71\%, 64\%, and 57\%, respectively. Genes iucA and IpfA $\mathrm{O} 157 / 01154_{1}$ were more frequently found among septicemic strains (54\% and 58\%, respectively), followed by fepC, IpfA $A_{0157 / 0 / 141}(30 \%)$, irp-2 (21\%), fyuA $(21 \%)$, iha $(21 \%)$, and sitA (17\%). All omphalitis strains presented the IpfA $A_{0157 / 0 / 154}$ sequence, four (36\%) presented the irp-2, fyuA, and sitA sequences, three (27\%) presented the iucA, two (18\%) presented sequence IpfA $A_{0157 / 0 / 141}$, and one (9\%) presented gene fepC (Table 2). The irp-2, fepC, iucA, and IpfA ${ }_{0157 / 01154}$ virulence sequences were more frequently found among pathogenic strains (Table 2). These differences were statistically significant (Pd"0.05).

Phylogenetic typing showed that the majority of commensal (87\%) and omphalitis (82\%) strains fell into Group A. Half of the septicemic strains were also allocated

Table 2. Distribution of virulence associated genes and phylogenetic groups among avian Escherichia coli strains ${ }^{a}$

\begin{tabular}{|c|c|c|c|c|c|c|c|c|c|c|}
\hline \multirow[t]{2}{*}{ VIR/PHY } & \multicolumn{5}{|c|}{ PR } & \multicolumn{5}{|c|}{ NU } \\
\hline & $C(30)$ & $S(24)$ & $\mathrm{H}(14)$ & $\mathrm{O}(11)$ & Pathogenic (49) & A (49) & $\mathrm{B} 1(6)$ & B2 (4) & $\mathrm{D}(20)$ & TO \\
\hline irp-2 & $4(13)$ & $5(21)$ & $10\left(71^{\star}\right)$ & $4(36)$ & $19(40)^{*}$ & $9(18)$ & $2(33)$ & $2(50)$ & $10(50)$ & $23(29)$ \\
\hline fyuA & $4(13)$ & $5(21)$ & $8(57)$ & $4(36)$ & $17(35)^{*}$ & $7(14)$ & $3(50)$ & $2(50)$ & $9(45)$ & $21(27)$ \\
\hline fepC & $1(3)$ & $7(30)$ & $11\left(79^{*}\right)$ & $1(9)$ & $19(40)^{*}$ & $5(10)$ & 0 & $1(25)$ & $14(70)$ & $20(25)$ \\
\hline sitA & $8(27)$ & $4(17)$ & $4(29)$ & $4(36)$ & $20(41)$ & $12(24)$ & $1(17)$ & $1(25)$ & $6(30)$ & $20(25)$ \\
\hline iucA & $4(13)$ & $13\left(54^{*}\right)$ & $9\left(64^{*}\right)$ & $3(27)$ & $25(51)^{\star}$ & $15(30)$ & $1(17)$ & $1(25)$ & $12(60)$ & $29(37)$ \\
\hline iha & $2(6)$ & $5(21)$ & 0 & $2(18)$ & $9(18)$ & $5(10)$ & 0 & 0 & $5(25)$ & $10(13)$ \\
\hline IpfA & $1(3)$ & $7(30)$ & 0 & 0 & $8(16)$ & $2(4)$ & 0 & 0 & $6(30)$ & $8(10)$ \\
\hline O157/O141 & & & & & & & & & & \\
\hline $\begin{array}{c}\text { IpfA } \\
0157 / 0154\end{array}$ & $6(20)$ & $14\left(28^{\star}\right)$ & $14\left(100^{*}\right)$ & $11\left(100^{*}\right)$ & $39(80)^{*}$ & $24(49)$ & $1(17)$ & $2(50)$ & $18(90)$ & $45(57)$ \\
\hline $\begin{array}{l}\text { Phylogenetic } \\
\text { group A }\end{array}$ & $25(83)$ & $12(50)$ & $3(21)$ & $9(82)$ & $24(50)$ & & & & & \\
\hline $\begin{array}{l}\text { Phylogenetic } \\
\text { group B1 }\end{array}$ & $4(13)$ & $2(8)$ & 0 & 0 & $2(4)$ & & & & & \\
\hline $\begin{array}{c}\text { Phylogenetic } \\
\text { group B2 }\end{array}$ & 1(3) & 0 & $2(14)$ & 0 & $2(4)$ & & & & & \\
\hline $\begin{array}{l}\text { Phylogenetic } \\
\text { group D }\end{array}$ & 0 & $10(42)$ & $9(64)$ & $1(9)$ & $20(41)$ & & & & & \\
\hline
\end{tabular}

${ }^{\mathrm{a}} \mathrm{C}=$ commensal avian $E$. coli strains, $\mathrm{S}=$ septicemic avian $E$. coli strains, $\mathrm{H}=$ swollen head syndrome avian $E$. coli strains, $\mathrm{O}=$ omphalitis avian E. coli strains, $\mathrm{PR}=$ Prevalence of different traits among avian E. coli strains (\%), NU = Number of strains harboring the virulence gene within phylogenetic group (\%), TO = Total of strains harboring a specific gene (\%), VIR/PHY = Virulence associated genes and phylogenetic groups, *significant values (P d" 0.05). 
in this phylogenetic group (Table 2). Sixty-four percent of the swollen head syndrome strains and $42 \%$ of the septicemic strains belonged to Group D. Few strains were allocated into Groups B1 and B2, respectively. None of the omphalitis strains belonged to Groups B1 and B2. Similarly, none of the swollen head syndrome strains were allocated in Group B1 and none of the septicemic strains belonged to Group B2 (Table 2).

The majority of the virulence-related genes were found in strains belonging to Groups $A$ and $D$ (Table 2). The irp2 , fyuA, fepC and IpfA ${ }_{0157 / 01141}$ sequences were more frequently found between strains belonging to $B 1, B 2$ and $\mathrm{D}$ phylogenetic groups. In contrast, the iha and IpfA $\mathrm{O}_{\mathrm{O} 157 /}$ O1154 sequences were found mainly among strains belonging to Group A (Table 2).

Thirty-five strains (6 commensal and 29 pathogenic) presented three to six genes in various genotypic combinations (Table 3). The irp-2+/fyuA ${ }^{+} /$fepC $^{+} / / p f \mathrm{~A}_{\mathrm{O} 157 /}$ ${ }^{0} 1{ }^{+}{ }^{+}$genotype was the most frequent (found in 5 strains). Thirteen strains ( 6 commensal, 3 septicemic and 4 omphalitis) presented only one gene. Among these, the IpfA $_{\mathrm{O} 157 / \mathrm{Ol154}}{ }^{+}$genotype was found in 10 strains (3 commensal, 4 omphalitis, and 3 septicemic); fyuA ${ }^{+}$ genotype was presented in two commensal strains and sitA $^{+}$genotype was detected in only one commensal strain. In addition, the Yersinia iron uptake-related genes fyuA (21 strains, 27\%) and irp-2 (22 strains, 28\%) were detected in association among 16 strains (20\% of all strains analyzed).
Among the thirty-five strains harboring three to six virulence-related genes, 13 (37\%) belonged to Group A (6 commensal, 4 omphalitis, 1 septicemic and 2 swollen head syndrome strains), $18(51 \%)$ to Group D (10 septicemic, 7 swollen head syndrome, 1 omphalitis strains), and 2 belonged to Group B2 (swollen head syndrome strains). The majority (94\%) of the strains harboring none or just one gene belonged to Group A (Table 3).

\section{DISCUSSION AND CONCLUSION}

In recent years, several investigations have demonstrated the presence of virulence- related sequences originally found on human pathogenic bacteria in APEC strains. These studies have suggested that APEC strains and bacterial human pathogens may show similar adaptations for an extra intestinal lifestyle, with APEC being able to cause disease in humans (Johnson et al. 2003, Mokady et al. 2005, Rodriguez-Siek et al. 2005, Stocki et al. 2005). In this study, we analyzed the presence of virulence genes related to adhesion and invasion to eukaryotic cells and tissues and the expression of iron uptake systems, which were originally described to be present in human pathogenic Escherichia coli, Yersinia and Shigella, among pathogenic and commensal avian E. coli strains, and associated these findings to the four major phylogenetic groups of $E$. coli (A, B1, B2, and D) described by Clermont et al. (2000).

Table 3. Occurrence of different genotypes among avian Escherichia coli strains ${ }^{a}$

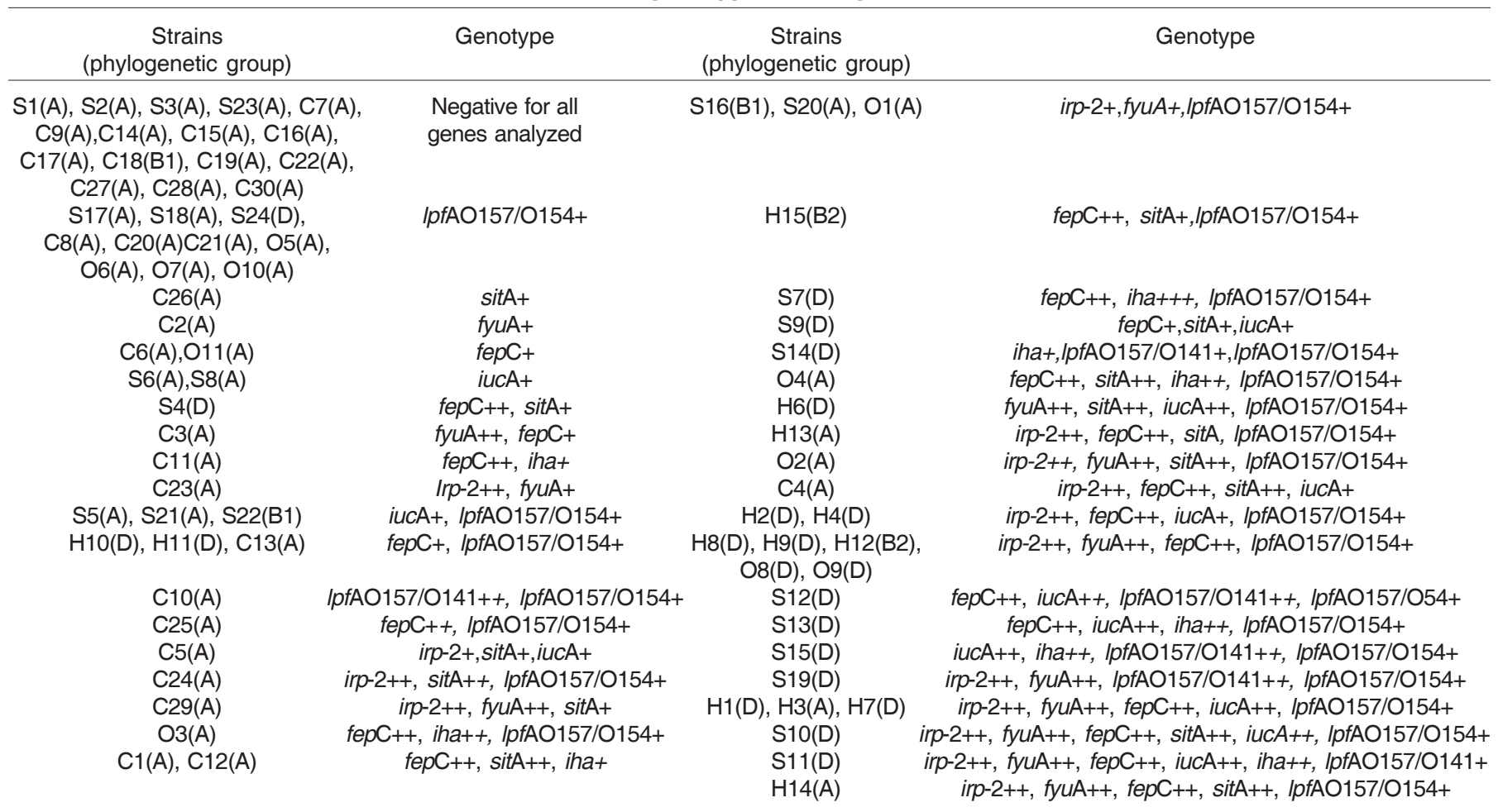

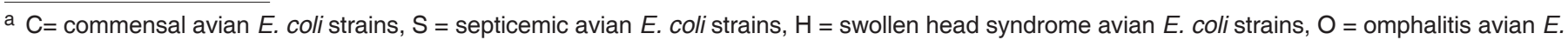
coli strains. 
Genes irp-2 and fyuA are DNA sequences present in the Yersinia high pathogencity island (HPI) (Carniel et al. 1996). The irp-2 gene encodes for a high molecular mass protein involved in the siderophore production and fyuA gene encodes for the yersiniabactin receptor (Lucier et al. 1996). These sequences have been found in $E$. coli pathogenic for humans and poultry in a high percentage (Schubert et al., 1998, Gophna et al. 2001, JanBen et al. 2001, Johnson et al. 2003, Ewers et al. 2004). In our study, genes irp-2 and fyuA were found in higher frequency ( $40 \%$ and $35 \%$, respectively) among pathogenic strains than among commensal strains (13\% for both genes), with differences statistically significant $(P=0.016$ and $P=0.03$, respectively) (Table 2). The higher frequencies of irp-2 and fyuA sequences among APEC strains found by us and the mentioned authors could suggest that these genes may be common in the APEC genome despite being originally described for Yersinia strains. Although these genes are described as being probably linked (JanBen et al. 2001, Ewers et al. 2004), in our study they were found in association among $60 \%$ of the strains.

The genes sitA, fepC and iucA are responsible for the expression of other iron uptake systems. The sitA gene belongs to the sit operon that was originally described within the centisome 63 of $S$. enterica Typhimurium Pathogenicity Island where gene sitA is a component of the $A B C$ iron transporter system and encodes for a putative periplasmic binding protein (Zhou et al. 1999). Gene fepC encodes for a ferric enterobactin transport ATP-binding protein involved in the enterobactin biosynthesis (Ratledge \& Dover 2000), and iucA encodes for a synthetase involved in the modification of hydroxylysin during the aerobactin synthesis (Okeke et al. 2004). These genes were found in Uropathogenic and Enteroaggretative E. coli (Guyer et al. 1998, Okeke et al. 2004). We detected fepC and iucA genes more frequently among septicemic and swollen head syndrome strains. Gene sitA was detected mainly in omphalitis, swollen head syndrome and commensal strains. Our results may suggest that $f e p C$ and iucA genes could be associated with the APEC strains studied in this work. In contrast, the higher frequency of sitA in commensal strains than in septicemic, and the similar frequencies of this gene among commensal and swollen head syndrome and omphalitis strains could indicate that this gene could not, per se, be related to the pathogenic mechanisms present in APEC. A recent study made by Sabri et al. (2006) showed that a SitABCD homologue system found in an APEC strain does not have a potential contribution to the virulence of the strain. These authors proposed that the contribution of SitABCD to the virulence of APEC could also differ among different APEC strains or serogroups. Our results could strengthen this suggestion.

Several strains possessed two or more iron uptake systems related genes. These results could indicate that these genes could be associated with the invasive capacity observed in APEC strains favoring its survival inside the hosts' tissues. The possession of diverse iron transport systems may reflect the multiple environments in which these bacteria grow up during disease. Different iron transport systems may be expressed at different times and in different locations during infection (Headly et al. 1997). The absence of invasion related sequences in all strains analyzed in this work does not mean that these strains are not invasive but could suggest that the strains harboring various iron uptake systems probably present invasion capacity that are not mediated by the genes studied in this work (inv and ial sequences) (Geyid et al. 1996).

Only three adhesin related sequences (iha, IpfA ${ }_{0157 /}$ $\mathrm{O}_{141}$, and $\left./ \mathrm{pfA}_{\mathrm{O} 157 / 01154}\right)$ were detected in the strains analyzed. The iha and IpfA ${ }_{\mathrm{O} 157 / \mathrm{O}_{141}}$ genes were found in lower frequencies among all strains. In contrast, gene IpfA $_{\text {O157/01154 }}$ was the most frequent gene detected, being found significantly among pathogenic strains, including all swollen head syndrome $(P=0.00001)$, omphalitis $(P=$ $0.00001)$ and septicemia strains $(P=0.005)$. Gene IpfA $\mathrm{O}_{0157 /}$ Ol154 is one of the four genetic variants of IfpA gene identified in STEC (Toma et al., 2004) and in other diarrheagenic E. coli strains (Toma et al. 2006). The IpfA encodes for the variants of the long polar fimbriae (LPF) that are adhesins related to Type 1 fimbriae, first identified in Salmonella enterica serovar Typhimurium (Bäumler et al. 1995). The higher frequency of $I p f A_{0157 / 0 / 154}$ among pathogenic avian $E$. coli analyzed in this work suggest that LPF could be a member of the colonization factors presented in these strains that are responsible for the adherence capacity described in previous studies (Silveira et al. 2002b, Amabile de Campos et al. 2005).

The PCR virulence gene detection showed that the majority of pathogenic avian E. coli strains have two or more virulence-related genes, mainly swollen head syndrome strains (Table 3 ). The presence of virulence related genes also found among human $E$. coli strains, demonstrated that APEC and human E. coli strains have similarities genomic that, probably permit APEC strains colonizes the same tissues colonized by human pathogenic E. coli. These features could characterize a zoonotic risk shown by APEC strains analyzed in this paper.

Those strains possessing groups of virulence-related genes but considered to be commensal, since they have been isolated from chickens showing no signs of diseases, could showed to be virulent in another host(s) were the immune system or the resident micro biota would be unbalanced.

Phylogenetic typing analysis for the major phylogenetic groups of E. coli (A, B1, B2, and D) demonstrated that most of the pathogenic strains analyzed belonged to the group $\mathrm{D}$, which is considered a pathogenic group of $E$. coli, and that the commensal ones belonged to the nonpathogenic E. coli group (Group A) (Clermont et al. 2000). The finding that the majority of omphalitis strains were classified in the non-pathogenic group of $E$. coli (Group A) suggests that these strains probably have a commensal origin and acts as opportunist pathogens causing omphalitis in chickens embryos as suggested in previous 
studies (Silveira et al. 2002a,b). By the other side, the classification of swollen head syndrome as derivate from pathogenic clonal groups (Group D), and the high frequency of virulence related genes among these strains suggest that $\mathrm{H}$ strains constitute a pathogenic clonal group inside the avian $E$. coli population analyzed. The same suggestion has been made in an ERIC-PCR study realized previously with the same population (Silveira et al. 2002a).

The allocation of $50 \%$ of the septicemic strains into group A suggests that these strains could have a commensal origin but would become pathogenic by horizontal acquisition of virulence-related genes. This suggestion could be made because the majority of septicemic strains have at least two of the pathogenic related sequences analyzed.

In conclusion, this work showed the occurrence of virulence-related sequences, mainly iron-uptake and adhesion-related genes, from human $E$. coli among pathogenic avian E. coli strains, and showed that APEC strains could be assigned into phylogenetic pathogenic groups similarly to those described by Clermont et al. (2000) for human pathogenic E. coli. The phylogenetic derivation from $E$. coli pathogenic clonal group (D) of major SHS strains suggested that these strains may constitute a pathogenic clonal lineage. Phylogenetic typing of septicemic APEC strains suggests that these strains may have two clonal origins: one from a pathogenic clonal group (represented by strains derivate from D clonal group) and one from a non pathogenic clonal group (represented by strains derivate from $A$ clonal group). The allocation of majority of omphalitis strains in Group A suggests that these strains constitute a non-pathogenic clonal group, and that omphalitis is probably a result from an opportunistic infection. The presence of virulence related sequences described originally in human $E$. coli suggests that APEC strains have genome similarities with these strains, which indicated that APEC strains can show a zoonotic risk.

Acknowledgments. - This study was supported by a fellowship granted to Tatiana Amabile de Campos by Campinas State University (Unicamp), by grant $n^{\circ} 303301 / 2002-3$ from the Brazilian Research Council (CNPq) and by grant $n^{\circ} 03 / 08407-0$ from Fundação de Amparo à Pesquisa do Estado de São Paulo (FAPESP).

\section{REFERENCES}

Amabile de Campos T., Stehling E.G., Ferreira A., Castro A.F.P., Brocchi M. \& Silveira W.D. 2005. Adhesion properties, fimbrial expression and PCR detection of adhesin-related genes of avian Escherichia coli strains. Vet. Microbiol. 106:275-285.

Ausubel F.M., Brente R., Kingston R.E., Moore D.D., Smith J.A., Seidman J.G. \& Struhl K. 1988. Cur. Prot. Mol. Biol. Green Publishing Associates, Brooklyn, NY.

Bäumler A.J. \& Heffron F. 1995. Identification and sequence analysis of IfpABCDE, a putative fimbrial operon of Salmonella typhimurium. Infect. Immun. 177(8):2087-2097.

Brito B.G., Gaziri L.C. \& Vidotto M.C. 2003. Virulence factors and clonal relationships among Escherichia coli strains isolated from broiler chickens with cellulitis. Infect. Immun. 71:4175-4177.
Carniel E., Guilvoule I., \& Prentice M. 1996. Characterization of a large chromosomal "high-pathogenicity island" in biotype 1B Yersinia enterocolitica. J. Bacteriol. 178:6743-6751.

Clermont O., Bonacorsi S. \& Bingen E. 2000. Rapid and simple determination of the Escherichia coliphylogenetic group. Appl. Environ. Microbiol. 66:4555-4558.

Dho-Moulin M. \& Fairbrother J.M. 1999. Avian pathogenic Escherichia coli (APEC). Vet. Res. 30:299-316.

Dozois C.M., Dho-Moulin M., Breé A., Fairbrother J.M., Desaultels C. \& Curtis III R. 2000. Relationship between the Tsh autotransporter and pathogenicity of avian Escherichia coli and localization and analysis of the tsh genetic region. Infect. Immun. 68:4145-4154.

Ewers C., Janssen T., Kiessling Philipp H-C. \& Wieler L.H. 2004. Molecular epidemiology of avian pathogenic Escherichia coli (APEC) isolated from colisepticemia in poultry. Vet. Microbiol. 104:91-101.

Geyid A., Fletcher J., Gashe B.A. \& Ljungh A. 1996. Invasion of tissue culture cells by diarrheagenic strains of Escherichia coli which lack the enteroinvasive inv gene. FEMS Immunol. Med. Microbiol. 14:1524.

Gophna U., Oelschlaeger T.A., Hacker J. \& Ron E.Z. 2001. Yersinia Hpi in septicemic Escherichia coli strains isolated from diverse hosts. FEMS Microbiol. Letters 196:57-60.

Gross W.B. 1994. Diseases due to Escherichia coli in poultry, p.237259. In: Gyles C.L. (Ed.), Escherichia coli in Domestic Animals and Humans. CAB International, Wallingford, UK.

Guyer D.M., Kao J.S. \& Mobley H.L.1998. Genomic analysis of a pathogenicity island in uropathogenic Escherichia coli CFT073: distribution of homologies sequences among isolates form patients with pyelonephritis, cystitis, and catheter-associated bacteriuria and from fecal samples. Infect. Immun. 66:4411-4417.

Janben T., Schwarz C., Preikschat P., Voss M., Philipp H.C. \& Wieler L.H. 2001. Virulence-associated genes in avian pathogenic Escherichia coli (APEC) isolated from internal organs of poultry having died from colibacillosis. Int. J. Med. Microbiol. 291:371-378.

Johnson T.J., Siek K.E., Johnson S.J. \& Nolan L.K. 2005. DNA sequence and comparative genomics of pAPEC-O2-R, an avian pathogenic Escherichia coli transmissible R plasmid. Antimicrob. Ag. Chemother. 49:4681-4688.

Johnson J.R., Murray A.C., Gajewsk A., Sullivan M., Snippes P., Kuskowisk M.A. \& Smith K.E. 2003. Isolation and molecular characterization of nalidixic acid resistant extra intestinal pathogenic Escherichia coli from retail chicken products. Antimicrob. Ag. Chemother. 47:2161-2168.

Johnson T.J., Siek K.E., Johnson S.J. \& Nolan L.K. 2006. DNA sequence of a ColV plasmid and prevalence of selected plasmid-encoded virulence genes among avian Escherichia coli strains. J. Bacteriol. 188:745-758.

Kariyawasam S., Johnson T.J. \& Nolan L.K. 2006. The pap operon of avian pathogenic Escherichia coli strain 01:K1 is located on a novel pathogenicity island. Infect. Immun.74:744-749.

Knöbl T., Baccaro M.R., Moreno A.M., Gomes T.A.T., Vieira M.A.M., Ferreira C.S.A. \& Ferreira A.J.P. 2001. Virulence properties of Escherichia coli isolated form ostriches with respiratory disease. Vet. Microbiol. 83:71-80.

La Ragione R.M. \& Woodward M.J. 2002. Virulence factors of Escherichia coli serotypes associated with avian colisepticemia. Res. Vet. Sci. 73:27-35

Lucier T.S., Fetherston J.D., Brubaker R.R. \& Perry R.D. 1996. Iron uptake and iron-repressible polypeptides in Yersinia pestis. Infect. Immun. 64:3023-3031.

Maurer J.J., Brown T.P., Steffens W.L. \& Thayer S.G. 1998. The occurrence of ambient temperature-regulated adhesins, curli, and the temperature-sensitive hemagglutinin Tsh among avian Escherichia coli. Avian Dis. 42:106-118. 
McPeake S.J.W., Smyth J.A. \& Ball H.J. 2005. Characterization of avian pathogenic Escherichia coli (APEC) associated with colisepticemia compared to fecal isolates form healthy birds. Vet. Microbiol. 110:245253.

Mokady D., Gophna U. \& Ron E.Z. 2005. Extensive gene diversity in septicemic Escherichia coli strains. J. Clin. Microbiol. 43:66-73.

Nataro J.P. \& Kaper J.B. 1998. Diarrheagenic Escherichia coli. Clin. Microbiol. Rev. 11:142-201.

Ngeleka M., Brereton L., Brown G. \& Fairbrother J.M. 2002. Pathotypes of avian Escherichia coli as related to tsh-, pap-, pil-, and iuc-DNA sequences, and antibiotic sensitivity of isolated from internal tissues and the cloacae of broilers. Avian Dis. 46:143-152.

Nicholls L., Grant T.H. \& Robins-Browne R.M. 2000. Identification of a novel genetic locus that is required for in vitro adhesion of a clinical isolate of enterohaemorrhagic Escherichia coli to epithelial cells. Mol. Microbiol. 35:275-288.

Okeke I.N., Scaletsky I.C.A., Soars E.H., Macfarlane L.R. \& Torres A.G. 2004. Molecular epidemiology of the iron utilization genes of enteroaggregative Escherichia coli. J. Clin. Microbiol. 42:36-44.

Parreira V.R. \& Gyles C.L. 2003. A novel pathogenicity island integrated adjacent to the thrW tRNA gene of avian pathogenic Escherichia coli encodes a vacuolating autotransporter toxin. Infect. Immun. 71:50875096.

Rasmussen H.N., Andersen J.K. \& Olsen J.E. 1994. Specific detection of pathogenic Yersinia enterocolitica by two-step PCR using hot-start and DMSO. Mol. Cell Prob. 8:99-108.

Ratledge C. \& Dover L.G. 2002. Iron metabolism in pathogenic bacteria. Annu. Rev. Microbiol. 54:881-941.

Rodriguez-Siek K.E., Giddings C.W., Doetkott C., Johnson T.J., Fakhr M.K. \& Nolan L.K. 2005. Comparison of Escherichia coli isolates implicated in humans urinary tract infection and avian colibacillosis. Microbiol 151:2097-2110.

Runyen-Janecky L.J., Reeves S.A., Gonzales E.G. \& Payne S.M. 2003. Contribution of the Shigella flexneri Sit, luc, and Feo iron acquisition systems to iron acquisition in vitro and in cultured cells. Infect. Immun. 71:1919-1928

Sabri M., Léveillé S. \& Dozois C.M. 2006. A SitABCD homologue from an avian pathogenic Escherichia coli strain mediates transport of iron and manganese and resistance to hydrogen peroxide. Microbiol. 152:745-758

Schmidt H., Zhang W.L, Hemmrich U.S., Jelacie S., Brunder W., Tarr P.I., Dobrindt U., Hacker J. \& Karch H. 2000. Identification and characterization of a novel genomic island integrated at selC in locus of enterocyte effacement-negative, Shiga toxin-producing Escherichia coli. Infect. Immun.69:6863-6873.

Schubert S., Rakin A., Karch H., Carniel E. \& Heesemann J. 1998. Prevalence of the "high-pathogenicity island" of Yersinia species among
Escherichia coli strains that are pathogenic to human. Infect. Immun. 66:480-485.

Silveira W.D., Ferreira A., Lancellotti M., Barbosa I.A., Leite D.S., de Castro A.F. \& Brocchi M. 2002a. Clonal relationship among Escherichia coli isolates determined by enterobacterial repetitive intergenic consensus (ERIC-PCR). Vet. Microbiol. 89:29-39.

Silveira W.D.S., Ferreira A., Brocchi M., Hollanda L.M., Pestana de Castro A.F., Yamada A.T. \& Lancellotti M. 2002b. Biological characteristics and pathogenicity of avian Escherichia coli strains. Vet. Microbiol. 85:47-53.

Skyberg J.A., Horne S.M., Giddings C., Wooley R.E., Gibbs P.S. \& Nolan L. 2003. Characterizing avian Escherichia coli isolates with multiplex polymerase chain reaction. Avian Dis. 47:1441-1447.

Stehling E.G., Campos T.A., Ferreira A. \& Silveira W.D. 2003a. Adhesion and Invasion Characteristics of a septicemic avian Escherichia coli strain are plasmid mediated. J. Appl. Res. Vet. Med. 1:27-36.

Stehling E.G., Yano T., Brocchi M. \& Silveira W.D. 2003b. Characterization of a plasmid-encoded adhesin of an avian pathogenic Escherichia coli (APEC) strain isolated form a case of swollen head syndrome (SHS). Vet. Microbiol. 95:11-120.

Stocki S.L., Babiuk L.A., Rawlyk N.A., Potter A.A. \& Allan B.J. 2002. Identification of genomic differences between Escherichia coli strains pathogenic for poultry and E. coli K-12 MG1655 using suppression subtractive hybridization analysis. Microbiol. Pathogenesis 33:289-298.

Szalo I.M., Goffaux F., Pirson V., Pierard D., Ball H. \& Mainil J. 2002. Presence of bovine enteropathogenic (EPEC) and enterohaemorrhagic (EHEC) Escherichia coli of genes encoding for putative adhesions of human EHEC strains. Res. Microbiol. 153:653-658.

Tarr C.L., Large T.M., Moeller C.L. Lacher D.W., Tarr P.I., Acheson D.W. \& Whittam T.S. 2002. Molecular characterization of a serotype O121:H19 clone, a distinct Shiga toxin-producing clone of pathogenic Escherichia coli. Infect. Immun.70:6853-6859.

Toma C., Espinosa E.M., Song T., Miliwebsky E., Chinen I., Iyoda S., Iwanaga M. \& Rivas M. 2004. Distribution of putative adhesin in different seropathotypes of Shiga toxin-producing Escherichia coli. J. Clin. Microbiol. 42:4937-4946.

Toma C., Higa N., lyoda S., Rivas M. \& Iwanaga M. 2006. The long polar fimbriae genes identified in Shiga toxin-producing Escherichia coli are present in other diarrheagenic $E$. coli in the standard $E$. coli collection of reference (ECOR) strains. Res. Microbiol. 157:153161.

Ye C. \& Xu J. 2001. Prevalence of iron transport gene on pathogenicityassociated island of uropathogenic Escherichia coli $0157: \mathrm{H} 7$ containing Shiga toxin gene. J. Clin. Microbiol. 39:2300-2305.

Zhou D., Hardt W.D. \& Galan J.E. 1999. Salmonella typhimurium encodes a putative iron transport system within the centisome 63 pathogenicity island. Infect. Immun. 67:1974-1981. 